\title{
Perbandingan Hasil Uji Performans Calon Induk (Heifer) Sapi Aceh dengan Metode Indeks Seleksi (IS) dan Nilai Pemuliaan (NP)
}

\author{
W. P. B. Putra ${ }^{1 *}$, Sumadi ${ }^{2}$, T. Hartatik ${ }^{2}$ dan H. Saumar ${ }^{3}$ \\ ${ }^{1}$ Universitas Muhammadiyah Gorontalo \\ Jl. Prof. Dr. Mansoer Pateda, Pentadio Timur, Gorontalo, 96181 \\ ${ }^{2}$ Fakultas Peternakan, Universitas Gadjah Mada Yogyakarta. \\ Jl. Fauna No. 3 Bulaksumur, Yogyakarta, 55281 \\ ${ }^{3}$ Balai Pembibitan Ternak Unggul - Hijauan Pakan Ternak (BPTU-HPT) Sapi Aceh Indrapuri \\ Jl. Medan-Banda Aceh Km. 25, Indrapuri, Aceh, 23363 \\ E-mail: banchet_putra18@yahoo.co.id
}

\begin{abstract}
ABSTRAK
Penelitian ini bertujuan untuk melihat hasil seleksi pada calon pejantan sapi Aceh menggunakan metode nilai pemuliaan (NP) dan indeks seleksi (IS) terhadap performans berat badan. Data sekunder yang digunakan dalam penelitian ini terdiri dari data recording ternak dari tahun 2010 sampai 2014 yang meliputi data silsilah ternak, data kelahiran dan data berat badan di Balai Pembibitan Ternak Unggul (BPTU) - Hijauan Pakan Ternak (HPT) Sapi Aceh Indrapuri. Data recording ternak yang diperoleh digunakan untuk mengestimasi heritabilitas, korelasi genetik dan korelasi fenotip. Hasil penelitian menunjukkan bahwa heritabilitas berat sapih (BS), berat setahunan (BY) dan berat akhir (BA) termasuk kategori tinggi. Korelasi genetik BS dengan BY dan BS dengan BA termasuk kategori positif sedang. Kesimpulan penelitian ini adalah terdapat 14 ekor heifer (48\%) yang memiliki peringkat $\mathrm{NP}_{\mathrm{BA}}$ dan IS yang sama dari 29 ekor heifer yang diuji. Metode IS dapat digunakan sebagai salah satu kriteria seleksi ternak yang lebih akurat.
\end{abstract}

Kata kunci: Sapi Aceh, nilai pemuliaan, indeks seleksi, heritabilitas, korelasi genetik

\section{The Comparison of Performance Test Results on Aceh Candidate Cow (Heifer) by Selection Index (SI) and Breeding Value (BV) Methods}

\begin{abstract}
This research was conducted to investigate the results of selection in Aceh cattle candidate bull using breeding value (BV) and selection index (SI) methods. The Secondary data in this research was records data from 2010 to 2013 and consisted of family tree, birth and body weight records at Indrapuri's Breeding and Forages Centre (IBFC) of Aceh Cattle. Data records collected for estimate heritability nor the genetic and phenotypic correlations. The research showed that heritability value of weaning weight $(W W)$, yearling weight $(Y W)$ and final weight $(F W)$ included high category. Genetic correlation between $W W$ with $Y W$ and $F W$ were positively moderate. The concluded of this research was $48 \%$ heifers had same rank on $B V_{F W}$ and SI from 29 heifers. Index selection method could be use for livestock selection criteria.
\end{abstract}

Key words: Aceh cattle, breeding value, selection index, heritability, genetic correlations

\section{PENDAHULUAN}

Sapi Aceh ditetapkan sebagai rumpun sapi asli Indonesia pada tahun 2011 oleh Mentri Pertanian RI melalui Keputusan Menteri Pertanian Nomor: 2907/Kpts/OT.140/6/2011 (Jamaliah, 2010). Sapi Aceh memiliki kemampuan cepat 
beradaptasi pada berbagai jenis pakan lokal antara lain dedaunan, rumput dan leguminosa baik dalam keadaan segar maupun kering (Umartha, 2005). Pemerintah sejak tahun 1978 membentuk Balai Pembibitan Ternak Unggul-Hijauan Pakan Ternak (BPTU-HPT) untuk menjaga kemurnian sapi Aceh dengan tujuan mendapatkan bibit yang baik dengan menerapkan teknik pemuliaan dan pemurnian sapi Aceh, uji penampilan, uji zuriat kelompok ternak terseleksi dan pemanfaatan pejantan dan betina unggul melalui inseminasi buatan (IB) dan kawin alam (Jamaliah, 2010). Kebutuhan yang mendesak saat ini dalam upaya peningkatan produktivitas sapi Aceh di Provinsi Aceh adalah tersedianya induk yang berkualitas tinggi, baik untuk perkawinan alam dan IB. Induk yang berkualitas tinggi dapat diperoleh dengan cara seleksi pada calon induk (candidate cow) berdasarkan pada nilai pemuliaan (NP) masing-masing individu. Sampai saat ini BPTU-HPT Sapi Aceh Indrapuri masih menggunakan metode nilai pemuliaan (NP) untuk melakukan seleksi ternak karena perhitungan parameter genetik antara lain heritabilitas dan korelasi genetik belum pernah dilakukan. Salah satu metode yang paling akurat untuk mengestimasi NP adalah menggunakan indeks seleksi (IS). Keunggulan metode ini adalah semua informasi performans individu ikut dianalisis, sehingga perhitungan pada metode ini menjadi lebih kompleks. Penelitian ini bertujuan untuk mengevaluasi NP sapi-sapi calon pejantan yang diestimasi dengan metode IS.

\section{MATERI DAN METODE}

Materi yang digunakan dalam penelitian ini berupa data catatan produksi sapi Aceh yang dipelihara di BPTU-HPT dari tahun 2010 sampai 2014 yang meliputi data berat badan, catatan kelahiran dan silsilah ternak.

Data berat badan dikoreksi terhadap jenis kelamin dan umur induk. Berat sapih, berat setahunan dan berat akhir masing- masing dikoreksi terhadap umur 205 hari, 365 hari dan 550 hari. Rumus yang digunakan untuk memperoleh berat badan terkoreksi dilakukan menurut petunjuk Hardjosubroto (1994) sebagai berikut:

$$
\begin{aligned}
& \mathrm{BS}_{\mathrm{T}}=\left(\frac{\mathrm{BS}-\mathrm{BL}}{\text { umur }} \times 205+\mathrm{BL}\right) \times(\mathrm{FKUI}) \times(\mathrm{FKJK}) \\
& \mathrm{BY}_{\mathrm{T}}=\left(\frac{\mathrm{BY}-\mathrm{BS}}{\text { tenggang waktu }} \times 160+\mathrm{BS}_{\mathrm{T}}\right)(\mathrm{FKJK}) \\
& \mathrm{BA}_{\mathrm{T}}=\left(\frac{\mathrm{BA}-\mathrm{BS}}{\text { tenggang waktu }} \times 345+\mathrm{BS}_{\mathrm{T}}\right)(\mathrm{FKJK})
\end{aligned}
$$

Keterangan:

$$
\begin{aligned}
& \mathrm{BS}=\text { berat sapih } \\
& \mathrm{BY}=\text { berat yearling atau setahunan } \\
& \mathrm{BA}=\text { berat akhir } \\
& \mathrm{BL}_{\mathrm{T}}=\text { berat lahir terkoreksi } \\
& \mathrm{BS}_{\mathrm{T}}=\text { berat sapih terkoreksi ke umur } 205 \\
& \text { hari } \\
& \mathrm{BY}_{\mathrm{T}}=\text { berat yearling atau setahunan } \\
& \text { terkoreksi ke umur } 365 \text { hari } \\
& \mathrm{BA}_{\mathrm{T}} \text { = berat akhir terkoreksi ke umur } 550 \\
& \text { hari }
\end{aligned}
$$

Faktor koreksi umur induk (FKUI) berat sapih dilakukan sesuai rekomendasi Hardjosubroto (1994) dihitung dengan faktor perkalian sebagai berikut: umur induk 2 tahun $(1,15) ; 3$ tahun $(1,10) ; 4$ tahun $(1,05)$; 5 sampai 10 tahun $(1,00)$ dan 11 tahun keatas $(1,05)$. Faktor koreksi jenis kelamin (FKJK) untuk berat badan pada penelitian ini tersaji pada Tabel 1.

\section{Analisis Data}

\section{Heritabilitas}

Estimasi nilai heritabilitas menggunakan metode korelasi saudara tiri sebapak (paternal halfsib correlation). Pemisahan komponen ragam untuk menduga heritabilitas dilakukan dengan analisis ragam menggunakan Rancangan Acak Lengkap Pola Searah (Completely Randomized Design One-Way Classification) dengan model menurut Becker (1992), Hardjosubroto (1994) dan Warwick et al. (1990) sebagai berikut: 
Tabel 1. Komponen ragam $\left(\sigma^{2}\right)$, peragam (côv), heritabilitas $\left(\mathrm{h}^{2}\right)$, korelasi genetik $\left(\mathrm{r}_{\mathrm{G}}\right)$ dan korelasi fenotip $\left(r_{P}\right)$ pada sifat pertumbuhan sapi Aceh di BPTU-HPT Sapi Aceh Indrapuri

\begin{tabular}{lccc}
\hline & Komponen & \multicolumn{3}{c}{ Berat badan $(\mathrm{kg})$} \\
\cline { 2 - 4 } & $\mathrm{BS}$ & $\mathrm{BY}$ & $\mathrm{BA}$ \\
\hline$\Sigma$ Pejantan & 4 & 4 & 4 \\
$\Sigma$ Anak & 48 & 48 & 48 \\
FKJK & 1,03 & 1,05 & 1,06 \\
$\sigma_{\mathrm{S}}^{2}$ & 12,92 & 38,28 & 93,21 \\
$\Sigma_{\mathrm{W}}^{2}$ & 93,98 & 274,18 & 575,67 \\
$\mathrm{~h}^{2}$ & $0,48+0,58$ & $0,49+0,58$ & $0,56+0,69$ \\
\hline
\end{tabular}

\begin{tabular}{|c|c|c|c|}
\hline \multicolumn{4}{|l|}{ Sifat BS } \\
\hline$\Sigma$ Pejantan & - & 3 & 3 \\
\hline$\Sigma$ Anak & - & 24 & 24 \\
\hline $\operatorname{côv}_{S}$ & - & 10,24 & 12,94 \\
\hline $\operatorname{côv}_{W}$ & - & 76,62 & 92,52 \\
\hline $\mathrm{r}_{\mathrm{G}}$ & - & 0,46 & 0,37 \\
\hline $\mathrm{r}_{\mathrm{P}}$ & - & 0,48 & 0,39 \\
\hline \multicolumn{4}{|l|}{ Sifat BY } \\
\hline$\Sigma$ Pejantan & - & - & 3 \\
\hline$\Sigma$ Anak & - & - & 24 \\
\hline $\operatorname{côv}_{S}$ & - & - & 23,37 \\
\hline $\operatorname{côv}_{W}$ & - & - & 160,69 \\
\hline $\mathrm{r}_{\mathrm{G}}$ & - & - & 0,39 \\
\hline$r_{p}$ & - & - & 0,40 \\
\hline
\end{tabular}

Keterangan: FKJK $=$ faktor koreksi jenis kelamin, $\mathrm{BS}=$ berat sapih terkoreksi 205 hari; $\mathrm{BY}=$ berat setahunan (yearling) terkoreksi 365 hari; $\mathrm{BA}=$ berat akhir terkoreksi 550 hari

$$
Y_{i k}=\mu+\sigma_{i}+e_{i k}
$$

Keterangan:

$\mathrm{Y}_{\mathrm{ik}} \quad=$ pengamatan pada individu ke-k pada pejantan ke-i

$\mu \quad=$ rata-rata populasi

$\sigma_{\mathrm{i}} \quad=$ efek pejantan ke-i

$\mathrm{e}_{\mathrm{ik}} \quad=$ penyimpangan efek lingkungan dan genetik yang tidak terkontrol dari setiap individu

Estimasi heritabilitas pada penelitian ini menggunakan metode korelasi saudara tiri sebapak (Paternal Halfsib Correlation Method) dengan rumus menurut Becker (1992) dan Hardjosubroto (1994) sebagai berikut:
Estimasi heritabilitas:

$h^{2}=\frac{4 \sigma_{\mathrm{S}}^{2}}{\sigma_{\mathrm{S}}^{2}+\sigma_{\mathrm{W}}^{2}}$

$S E h^{2}=4 \sqrt{\frac{2(1-t)^{2}[1+(k-1)(t)]^{2}}{k(k-1)(S-1)}}$

Dimana,

$\mathrm{t}=\frac{\sigma_{\mathrm{S}}^{2}}{\sigma_{\mathrm{S}}^{2}+\sigma_{\mathrm{W}}^{2}} \quad \mathrm{k}=\frac{1}{\mathrm{~S}-1}\left(\mathrm{~N}-\frac{\sum \mathrm{n}_{\mathrm{i}}^{2}}{\mathrm{~N}}\right)$

Keterangan:

$\mathrm{h}^{2} \quad=$ heritabilitas

$\mathrm{SE}=$ standard error atau simpangan baku

$\hat{\sigma}_{S}^{2} \quad=$ ragam pejantan

$\hat{\sigma}_{W}^{2} \quad=$ ragam keturunan dalam pejantan 
$\mathrm{S} \quad=$ jumlah pejantan

$\mathrm{N} \quad=$ jumlah anak keseluruhan

$\mathrm{n}_{\mathrm{i}} \quad=$ jumlah anak tiap pejantan

$\mathrm{t} \quad=$ korelasi dalam kelas sebapak

$\mathrm{k}=$ koefisien jumlah anak tiap pejantan

\section{Korelasi genetik}

Estimasi nilai korelasi genetik dan korelasi fenotip dilakukan sesuai petunjuk Becker (1992) sebagai berikut:

$\mathrm{r}_{\mathrm{G}}=\frac{\hat{\operatorname{cov}}_{\mathrm{S}}}{\sqrt{\hat{\sigma}_{\mathrm{S}(\mathrm{X})}^{2} \hat{\sigma}_{\mathrm{S}(\mathrm{Y})}^{2}}}$

Estimasi korelasi fenotip pada penelitian ini juga dihitung sebagai salah satu koefisien teknis dalam menghitung Indeks seleksi. Estimasi korelasi fenotip dihitung menggunakan rumus menurut Becker (1992) sebagai berikut:

$$
r_{p}=\frac{c \hat{o v}_{\mathrm{W}}+\hat{c o v}_{\mathrm{S}}}{\sqrt{\left(\hat{\sigma}_{\mathrm{S}(\mathrm{X})}+\hat{\sigma}_{\mathrm{W}(\mathrm{X})}\right)\left(\hat{\sigma}_{\mathrm{S}(\mathrm{Y})}+\hat{\sigma}_{\mathrm{W}(\mathrm{Y})}\right)}}
$$

Keterangan:

$\mathrm{r}_{\mathrm{G}} \quad=$ korelasi genetik

$\mathrm{r}_{\mathrm{P}} \quad=$ korelasi fenotip

$\mathrm{SE}=$ standard error atau simpangan baku

$\hat{\sigma}_{S(X)}^{2}=$ ragam pejantan $\mathrm{x}$

$\hat{\sigma}_{S(Y)}^{2}=$ ragam pejantan $\mathrm{y}$

$\hat{\sigma}_{W(X)}^{2}=$ ragam keturunan dalam pejantan $\mathrm{x}$

côv ${ }_{S}=$ komponen peragam sifat-sifat yang berhubungan dengan pejantan

côv $\mathrm{v}_{W}=$ komponen peragam sifat-sifat yang berhubungan dengan keturunan

\section{Nilai pemuliaan}

Nilai pemuliaan calon induk diestimasi menggunakan rumus ssesuai petunjuk Hardjosubroto (1994) sebagai berikut:

$\mathrm{NP}_{\text {Relatif }}=\mathrm{h}^{2}\left(\mathrm{P}_{\text {Ind }}-\overline{\mathrm{P}}_{\text {Pop }}\right)$

Keterangan:

$\mathrm{P}_{\text {Ind }}=$ rata-rata berat badan individu $\overline{\mathrm{P}}_{\text {Pop }}=$ rata-rata berat badan populasi

\section{Indeks seleksi}

Metode indeks seleksi berdasarkan pada performans $\mathrm{BS}_{\mathrm{T}}, \mathrm{BY}_{\mathrm{T}}$ dan $\mathrm{BA}_{\mathrm{T}}$ sesuai petunjuk Becker (1992) dan Warwick et al. (1990) dengan rumus persamaan indeks seleksi sebagai berikut:

$\mathrm{I}=\mathrm{b}_{1} \mathrm{X}_{1}+\mathrm{b}_{2} \mathrm{X}_{2}+\mathrm{b}_{3} \mathrm{X}_{3}$

Keterangan:

I = indeks seleksi

$\mathrm{b} \quad=$ faktor pembobot

$\mathrm{X}=$ pengukuran untuk sifat, diekspresikan sebagai selisih dari rata-rata kelompok

$\mathrm{n} \quad=$ jumlah sifat yang diukur

Nilai $b$ dihitung dengan matriks ragam-peragam dengan susunan sebagai berikut:

$\left[\begin{array}{ccc}\operatorname{Var} P\left(X_{1}\right) & \operatorname{CovP}\left(X_{1} X_{2}\right) & \operatorname{CovP}\left(X_{1} X_{3}\right) \\ \operatorname{CovP}\left(X_{2} X_{1}\right) & \operatorname{VarP}\left(X_{2}\right) & \operatorname{CovP}\left(X_{2} X_{3}\right) \\ \operatorname{CovP}\left(X_{3} X_{1}\right) & \operatorname{CovP}\left(X_{3} X_{2}\right) & \operatorname{VarP}\left(X_{3}\right)\end{array}\right]\left[\begin{array}{c}b_{1} \\ b_{2} \\ b_{3}\end{array}\right]^{-1}$

$\left[\begin{array}{ccc}\operatorname{VarG}\left(\mathrm{X}_{1}\right) & \operatorname{CovG}\left(\mathrm{X}_{1} \mathrm{X}_{2}\right) & \operatorname{CovG}\left(\mathrm{X}_{1} \mathrm{X}_{3}\right) \\ \operatorname{CovG}\left(\mathrm{X}_{2} \mathrm{X}_{1}\right) & \operatorname{VarG}\left(\mathrm{X}_{2}\right) & \operatorname{CovG}\left(\mathrm{X}_{2} \mathrm{X}_{3}\right) \\ \operatorname{CovG}\left(\mathrm{X}_{3} \mathrm{X}_{1}\right) & \operatorname{CovG}\left(\mathrm{X}_{3} \mathrm{X}_{2}\right) & \operatorname{VarG}\left(\mathrm{X}_{3}\right)\end{array}\right]\left[\begin{array}{c}\mathrm{a}_{1} \\ \mathrm{a}_{2} \\ \mathrm{a}_{3}\end{array}\right]$

$\left(\sigma_{\mathrm{i}}^{2}\right)$ atau $\operatorname{VarP}\left(\mathrm{X}_{\mathrm{n}}\right)=\left(\sum \mathrm{x}_{\mathrm{i}}{ }^{2}-\left(\Sigma \mathrm{x}_{\mathrm{i}}\right)^{2} / \mathrm{n}\right) /(\mathrm{n}-$

1) atau $\mathrm{SSX} /(\mathrm{n}-1)$

$\operatorname{CovP}\left(X_{1} X_{2}\right)=r_{p(x 1 . x 2)} \cdot \sigma_{1(x 1)} \cdot \sigma_{2}(x 2)$

$\operatorname{VarG}\left(\mathrm{X}_{\mathrm{i}}\right) \quad=\mathrm{h}_{\mathrm{i}}^{2} \cdot \sigma_{\mathrm{i}}^{2}$

$\operatorname{CovG}\left(\mathrm{X}_{1} \mathrm{X}_{2}\right) \quad=\mathrm{r}_{\mathrm{G}}(\mathrm{x} 1 . \mathrm{x} 2) \cdot\left(\sqrt{ } \mathrm{h}^{2}{ }_{(1)}\right.$

$\left.\mathrm{h}^{2}{ }_{(2)}\right) \cdot \sigma_{1(\mathrm{x} 1)} \cdot \sigma_{2(\mathrm{x} 2)}$

Keterangan :

$\mathrm{P} \quad=$ matriks fenotip

$\mathrm{P}^{-1} \quad=$ matriks kebalikan (inverse matrix)

dari matriks $P$

$\mathrm{G} \quad=$ matriks genotip

$\mathrm{B}=$ vektor faktor pembobot matriks $\mathrm{P}$

A = vektor faktor pembobot matriks $G$

$\operatorname{VarP}\left(\mathrm{X}_{\mathrm{i}}\right) \quad=$ ragam fenotip sifat ke-i

$\operatorname{VarG}\left(X_{i}\right) \quad=$ ragam genotip sifat ke-i

$\operatorname{CovP}\left(\mathrm{X}_{\mathrm{n}} \mathrm{X}_{\mathrm{n}-1}\right)=$ peragam fenotip antar sifat

$\operatorname{CovG}\left(X_{n} X_{n-1}\right)=$ peragam genotip antar sifat

$\mathrm{r}_{\mathrm{G}} \quad=$ korelasi genetik

$\mathrm{r}_{\mathrm{P}} \quad=$ korelasi

$\mathrm{h}^{2} \quad=$ heritabilitas 


\section{HASIL DAN PEMBAHASAN}

\section{Heritabilitas}

Komponen ragam dan peragam dari hasil estimasi heritabilitas dan korelasi genetik masing-masing ditampilkan pada Tabel 1. Komponen ragam dan peragam yang diperoleh selanjutnya digunakan untuk mengestimasi nilai heritabilitas dan korelasi genetik. Estimasi nilai heritabilitas sifat pertumbuhan sapi Aceh dan beberapa sapi potong di Indonesia dengan metode korelasi saudara tiri sebapak (paternal half-shib correlation) disajikan pada Tabel 2. Nilai heritabilitas $\mathrm{BS}_{\mathrm{T}}, \mathrm{BY}_{\mathrm{T}}$ dan $\mathrm{BA}_{\mathrm{T}}$ yang diperoleh termasuk kategori tinggi $(\geq 0,30)$ tetapi tidak handal karena memiliki nilai SE yang lebih tinggi dari nilai heritabilitas. Tingginya nilai SE pada penelitian ini disebabkan karena jumlah sampel (anak) dan pejantan (sire) yang diestimasi sedikit dan adanya variasi fenotip antar individu yang besar. Jumlah sampel yang diperlukan minimal 500 sampel agar nilai heritabilitas yang diperoleh handal (Warwick et al. (1990). Nilai heritabilitas pada penelitian ini dihitung berdasarkan asumsi sapi-sapi yang diestimasi tersebut mendapat pakan yang sama dan berada pada lingkungan yang sama, sehingga mutu genetik ternak dapat diukur. Nilai heritabilitas BS sebesar 0,48 menunjukkan bahwa keragaman BY pada populasi $48 \%$ dipengaruhi oleh faktor ragam genetik dari tetuanya. Sapi Golpayeganian memiliki nilai heritabilitas BS, BY dan BA berturut-turut sebesar 0,39; 0,48 dan 0,42 (Harighi, 2012) dan pada sapi Limmousine masing-masing sebesar 0,19 ; 0,16 dan 0,24 (Niekerk, 2006).

Sapi Charolais memiliki nilai heritabilitas BS dan BY masing-masing sebesar 0,23 (Utrera et al., 2010) dan sapi Red Chittagong masing-masing sebesar 0,47 dan 0,48 (Rabeya et al., 2009). Nilai heritabilitas BS sapi Simmental $(0,39)$, Madura $(0,87)$, Brahman cross $(0,37)$ dan Ongole $(0,27)$. Nilai heritabilitas BY pada sapi Simmental $(0,43)$, Madura $(0,27)$, Brahman cross $(0,44)$ dan Ongole sebesar
0,39 (Suhada, 2008; Karnaen, 2004; Duma, 1997). Sapi Bali memiliki nilai heritabilitas BS dan BY masing-masing sebesar 0,23 dan 0,38 (Sukmasari et al., 2002); 0,33 dan 0,43 (Gunawan dan Jakaria, 2011) selanjutnya 0,51 dan 0,54 (Kaswati et al., 2013).

Perbedaan nilai heritabilitas pada beberapa penelitian sebelumya disebabkan karena heritabilitas bukan merupakan konstanta dan bergantung pada jumlah populasi, waktu estimasi dan bangsa ternak (Falconer dan Mackay, 1996). Nilai heritabilitas BS, BY dan BA pada tergolong tinggi walaupun kurang handal untuk digunakan sebagai kriteria seleksi.

Seleksi pada sapi Aceh berdasarkan berat badan tetap dapat dilakukan karena sapi Aceh belum pernah diseleksi secara intensif dengan menggunakan parameter genetik, sehingga dapat diasumsikan bahwa sifat BS, BY dan BA masih memiliki keragaman genetik yang tinggi dan dapat digunakan sebagai kriteria seleksi. Suatu sifat yang memiliki angka pewarisan (heritabilitas) yang tinggi, sehingga diharapkan bahwa keunggulan suatu sifat yang dimiliki oleh tetua (pejantan) kelak akan diwariskan pada keturunannya. Sebaliknya jika nilai heritabilitas suatu sifat kecil maka keragaman genetik sifat tersebut juga akan kecil, sehingga seleksi berdasarkan sifat tersebut kurang memberikan respon terhadap peningkatan performans pada sifat tersebut (Falconer dan Mackay, 1996).

\section{Korelasi Genetik}

Korelasi genetik pada sifat pertumbuhan pada penelitian tersaji pada Tabel 1. Nilai korelasi genetik antara BS dengan BY dan BA pada penelitian ini termasuk kategori sedang $\left(0,30<\mathrm{r}_{\mathrm{G}}<0,50\right)$. Sapi Nellore memiliki nilai korelasi genetik pada sifat BS - BA dan BS - BY masing-masing sebesar 0,63 dan 0,71 (Regatieri et al. 2012). Sapi Limmousine memiliki nilai korelasi genetik antara sifat BS - BY sebesar 0,99 dan BS BA sebesar 0,93 (Niekerk 2006). Korelasi genetik antara sifat BS - BY 
Tabel 2. Peringkat hasil seleksi calon induk (heifer) sapi Aceh berdasarkan nilai pemuliaan (NP) dan indeks seleksi (IS) berat badan

\begin{tabular}{|c|c|c|c|c|c|c|c|}
\hline \multirow[t]{2}{*}{ No. Sapi } & \multicolumn{3}{|c|}{ Berat badan $(\mathrm{kg})$} & \multicolumn{3}{|c|}{ NP relatif (rank) } & \multirow{2}{*}{ IS (rank) } \\
\hline & BS & BY & $\mathrm{BA}$ & $\mathrm{BS}$ & BY & $\mathrm{BA}$ & \\
\hline A. 10.05 .26 & 67,91 & 110,77 & 136,13 & $11,06(1)$ & $20,80(1)$ & $24,40(2)$ & $579128,63(1)$ \\
\hline A. 10.04 .08 & 62,48 & 100,70 & 145,23 & $8,45(2)$ & $15,87(2)$ & $29,50(1)$ & $571036,34(2)$ \\
\hline A. 10.08 .08 & 59,55 & 79,65 & 91,73 & $7,04(3)$ & $5,55(8)$ & $-0,46(13)$ & $414731,03(11)$ \\
\hline A. 10.08 .07 & 58,63 & 79,48 & 116,34 & $6,60(4)$ & $5,47(9)$ & $13,32(6)$ & $463637,71(6)$ \\
\hline A. 10.03 .02 & 58,23 & 91,98 & 124,62 & $6,41(5)$ & $11,59(3)$ & $17,96(3)$ & $506377,16(3)$ \\
\hline A. 10.04 .27 & 57,74 & 85,39 & 117,36 & $6,17(6)$ & 8,37 (4) & $13,89(4)$ & $477230,53(4)$ \\
\hline A. 10.04 .04 & 53,30 & 83,97 & 112,53 & $4,04(7)$ & $7,67(5)$ & $11,19(7)$ & $459898,27(7)$ \\
\hline A. 10.06 .07 & 52,79 & 83,84 & 116,66 & $3,80(8)$ & $7,61(6)$ & $13,50(5)$ & $467532,29(5)$ \\
\hline A. 10.04 .25 & 50,82 & 80,34 & 108,12 & $2,85(9)$ & $5,89(7)$ & $8,72(8)$ & $440766,15(8)$ \\
\hline A. 10.01 .23 & 48,02 & 76,06 & 102,47 & $1,51(10)$ & $3,79(10)$ & $5,55(11)$ & $417415,35(10)$ \\
\hline A. 10.01 .26 & 48,03 & 74,98 & 106,14 & $1,51(10)$ & $3,26(11)$ & $7,61(9)$ & $422642,44(9)$ \\
\hline A. 10.08 .03 & 47,72 & 68,29 & 90,62 & $1,36(11)$ & $-0,02(15)$ & $-1,08(15)$ & $376620,61(14)$ \\
\hline A. 10.04 .03 & 47,34 & 74,15 & 90,35 & $1,18(12)$ & $2,86(12)$ & $-1,23(16)$ & $387993,93(13)$ \\
\hline A. 10.05 .18 & 46,67 & 72,96 & 104,34 & $0,86(13)$ & 2,27 (13) & $6,60(10)$ & $413350,27(12)$ \\
\hline A. 10.03 .10 & 44,46 & 69,02 & 91,19 & $-0,20(14)$ & $0,34(14)$ & $-0,76(14)$ & $376013,98(15)$ \\
\hline A. 10.04 .07 & 43,35 & 67,04 & 88,73 & $-0,73(15)$ & $-0,63(16)$ & $-2,14(17)$ & $365712,92(17)$ \\
\hline AP. 10.01 .22 & 42,24 & 65,84 & 93,13 & $-1,27(16)$ & $-1,21(17)$ & $0,32(12)$ & $371042,26(16)$ \\
\hline A. 10.01 .20 & 42,05 & 65,51 & 72,17 & $-1,35(17)$ & $-1,38(18)$ & $-11,41(24)$ & $327405,54(21)$ \\
\hline AP. 10.01 .21 & 39,06 & 59,40 & 82,92 & $-2,79(18)$ & $-4,37(19)$ & $-5,40(20)$ & 333468,59 (19) \\
\hline A. 10.04 .16 & 38,96 & 59,23 & 88,48 & $-2,84(19)$ & $-4,45(20)$ & $-2,28(18)$ & $344350,65(18)$ \\
\hline AP. 10.01 .04 & 37,68 & 57,72 & 80,89 & $-3,46(20)$ & $-5,19(21)$ & $-6,53(21)$ & $324401,20(22)$ \\
\hline A. 10.05 .27 & 36,79 & 55,37 & 86,45 & $-3,88(21)$ & $-6,35(22)$ & $-3,42(19)$ & $329903,83(20)$ \\
\hline A. 10.01 .15 & 35,86 & 54,48 & 76,01 & $-4,33(22)$ & $-6,78(23)$ & $-9,26(22)$ & $305798,27(23)$ \\
\hline A. 10.03 .07 & 35,02 & 51,43 & 70,40 & $-4,73(23)$ & $-8,28(25)$ & $-12,41(25)$ & $287098,30(25)$ \\
\hline AP. 10.04 .28 & 34,54 & 52,13 & 72,46 & $-4,96(24)$ & $-7,93(24)$ & $-11,25(23)$ & $292284,06(24)$ \\
\hline A. 10.01 .16 & 33,25 & 49,84 & 69,02 & $-5,58(25)$ & $-9,05(26)$ & $-13,18(26)$ & $279150,64(26)$ \\
\hline A.11.02.02 & 29,72 & 41,22 & 54,50 & $-7,28(26)$ & $-13,28(27)$ & $-21,31(27)$ & $227852,39(27)$ \\
\hline A. 10.09 .02 & 27,55 & 39,69 & 53,72 & $-8,32(27)$ & $-14,03(28)$ & $-21,75(28)$ & $220849,32(28)$ \\
\hline \multirow[t]{2}{*}{ A. 10.05 .01} & 21,67 & 30,78 & 41,32 & $-11,14(28)$ & $-18,39(29)$ & $-28,69(29)$ & $170885,26(29)$ \\
\hline & $44,88+11$, & $68,32+18$ & $92,55+24$ & - & - & - & -2 \\
\hline Rata-rata (kg) & $\begin{array}{r}-16 \\
\end{array}$ & $\begin{array}{r}, 17 \\
\end{array}$ &, 32 & & & & \\
\hline
\end{tabular}

Keterangan: $\mathrm{BS}=$ berat sapih yang dikoreksi ke umur 205 hari, BY = berat satu tahun yang dikoreksi ke umur 365 hari, $\mathrm{BA}=$ berat akhir yang dikoreksi ke umur 550 hari

pada sapi Simmental $(0,68)$, Brahman cross $(0,71)$, Ongole $(0,74)$, Bali $(0,72)$ dan Madura $(0,59)$ termasuk kategori tinnggi $(\geq$ 0,50) (Suhada, 2008; Duma, 1997; Sukmasari et al., 2012; Karnaen, 2004).

Nilai korelasi genetik sifat-sifat pertumbuhan (BS, BY dan BA) pada sapi Aceh termasuk kategori positif sedang, sehingga dapat digunakan sebagai dasar kriteria seleksi ternak khususnya oleh BPTU-HPT Sapi Aceh. Keragaman genetik pada sifat-sifat pertumbuhan dalam populasi sapi Aceh yang tinggi disebabkan karena belum dilakukan seleksi ternak terhadap sifat-sifat pertumbuhan yang intensif. Seleksi pada BS dapat meningkatkan BY demikian pula seleksi pada BY dapat meningkatkan BA pada sapi Aceh.

\section{Nilai Pemuliaan dan Indeks Seleksi}

Hasil estimasi NP berat badan pada 29 calon induk sapi Aceh (Tabel 2) menunjukkan bahwa sebagian besar calon induk (heifer) sapi Aceh memiliki peringkat berbeda pada setiap periode berat badan. Perbedaan peringkat pada setiap periode berat badan dalam individu disebabkan oleh pengaruh lingkungan yang berbeda pada setiap periode berat badan. Estimasi $\mathrm{NP}_{\mathrm{BA}}$ digunakan sebagai salah satu kriteria seleksi ternak untuk memilih calon induk sapi Aceh di BPTU-HPT Sapi Aceh Indrapuri. Selain berdasarkan sifat kuantitatif (berat badan), seleksi heifer sapi Aceh juga didasarkan pada sifat kualitatif (warna tubuh). Pada penelitian ini semua heifer sapi Aceh memiliki warna tubuh yang sesuai dengan standar bibit yaitu merah bata. Hasil estimasi dengan metode $\mathrm{NP}_{\mathrm{BA}}$ dan IS menunjukkan bahwa terdapat 14 ekor sapi (48\%) yang memiliki kesamaan peringkat pada kedua metode tersebut. Perbedaan peringkat antara IS dan $\mathrm{NP}_{\mathrm{BA}}$ disebabkan karena pada metode IS semua performans individu yang memiliki nilai ekonomi tinggi ikut 
digunakan dalam estimasi. Sebagai contoh individu nomor AP.10.05.26 memiliki peringkat $\mathrm{NP}_{\mathrm{BA}}$ kedua, akan tetapi jika diestimasi dengan metode IS memiliki peringkat pertama. Perbedaan peringkat (ranking) tersebut disebabkan karena sapi nomor AP.10.05.26 memiliki $\mathrm{NP}_{\mathrm{BS}}$ dan $\mathrm{NP}_{\mathrm{BY}}$ masing-masing peringkat pertama, sehingga kedudukan sapi berdasarkan metode IS menjadi peringkat pertama. Metode IS lebih akurat untuk seleksi ternak dibanding metode NP karena semua variabel sifat produksi ikut dianalisis. Nilai NP yang negatif menunjukkan bahwa kedudukan ternak dalam suatu populasi berada di bawah rata-rata populasinya (Hardjosubroto, 1994). Berdasarkan Tabel 2 terdapat 12 ekor (41\%) Heifer yang memiliki $\mathrm{NP}_{\mathrm{BA}}$ positif. Heifer yang memiliki $\mathrm{NP}_{\mathrm{BA}}$ positif sebagian besar memiliki peringkat yang sama terhadap IS. Kelemahan metode IS dalam seleksi ternak adalah perhitungannya lebih kompleks karena diperlukan banyak koefisien teknis antara lain $\mathrm{h}^{2}, \mathrm{r}_{\mathrm{G}}$ dan $\mathrm{r}_{\mathrm{P}}$.

\section{SIMPULAN}

Persamaan indeks seleksi (I) yang diperoleh dari hasil penelitian ini adalah: $\mathrm{I}=$ 1013,07 (BS) + 2100,51 (BY) + 2039,65 (BA). Persamaan tersebut secara akurat dapat digunakan untuk memilih calon induk/calon pejantan yang terbaik khususnya di BPTU-HPT Sapi Aceh Indrapuri berdasarkan performans berat badannya.

\section{UCAPAN TERIMA KASIH}

Penulis menyampaikan terima kasih kepada seluruh staf dan karyawan di BPTUHPT Sapi Aceh Indrapuri atas bantuan dan dukungannya sehingga penelitian ini dapat diselesaikan dengan baik.

\section{DAFTAR PUSTAKA}

Becker, W. A. 1992. Manual of Quantitative Genetics. Cetakan ke-8. Washington State University,USA.

Duma, Y. 1997. Estimasi Beberapa Parameter Genetik pada Sapi Brahman Cross dan
Ongole di Ladang Ternak Bila River Ranch. Tesis. Program Pascasarjana, Universitas Gadjah Mada, Yogyakarta.

Falconer, D. S. and Mackay, T. F. 1996. Introduction to Quantitative Genetics. Cetakan ke-4. Department of Genetics. North Canada State University, Canada.

Gunawan, A. and Jakaria. 2011. Genetic and non genetic effect on birth, weaning and yearling weight in Bali cattle. Media Peternakan. 34(2): 93-98.

Hardjosubroto, W. 1994. Aplikasi Pemuliabiakan Ternak di Lapangan. Gramedia Widiasarana Indonesia, Jakarta.

Harighi, M.F. 2007. Estimated of genetic parameters of growth Golpayeganian calves. Pakistan Journal of Biology Sciences. 5: 112-115.

Jamaliah. 2010. Pelestarian Plasma Nutfah Sapi Aceh. Balai Pembibitan Ternak Unggul (BPTU) Sapi Aceh Indrapuri, Aceh.

Karnaen. 2004. Pendugaan parameter genetik, korelasi genetik dan fenotipik pada Sapi Madura. Journal of Indonesian Tropical Animal and Agriculture. 25:12-24.

Kaswati, Sumadi, N. Ngadiono. 2013. Estimasi nilai heritabilitas berat lahir, sapih dan umur satu tahun pada sapi Bali di Balai Pembibitan Ternak Unggul Sapi Bali. Buletin Peternakan. 37:74-78.

Niekerk, M. and F.W.C. Neser. 2006. Genetic parameters for growth traits in South African Limmousine cattle. South Africa Journal of Animal Science. 36: 6-9.

Rabeya, T., A.K.F.H. Bhuiyan, M.A. Habib and M.S. Hossain. 2009. Phenotypic and genetic parameters for growth traits in Red Chittagong cattle. Journal of Bangladesh Agriculture. University. 7: 265-271.

Regatieri, I.C., A.A. Boligon, F. Baldi and L.G. Alburquerque. 2012. Genetic correlations between mature cow weight and productive and reproductive traits in Nellore cattle. Genetics and molecular research. 11: 2979-2986.

Suhada, H. 2008. Estimasi parameter genetik sifat produksi sapi Simmental Di Balai Pembibitan Ternak Unggul Sapi Potong Padang Mengatas Sumatera Barat. Tesis. Program Pascasarjana, Universitas Gadjah Mada, Yogyakarta.

Umartha, B.A. 2005. Mengenal Karakteristik Sapi Aceh. Balai Pembibitan Ternak 
Unggul (BPTU) Sapi Aceh Indrapuri, Banda Aceh.

Utrera, A.R., V.E.V. Murillo, G.M. Velazquez and M.M. Bermudez. 2010. Estimation of genetic effects for growth traits of Mexican Charolais cattle using alternative models. Livestock Prodoction Science. 60: 203-208.

Warwick, E.J., J.W. Astuti, W. Hardjosubroto. 1990. Pemuliaan Ternak. Gadjah Mada University 